Bentham open

RESEARCH ARTICLE

\title{
A VA Perspective: The Expanding Role of the Clinical Health Psychologist in the New Era of Hepatitis $C$ and Advanced Liver Disease Clinical Care
}

\author{
Rose A. Gonzalez ${ }^{1,2, *}$, Erin C. Watson ${ }^{3}$, F. Nicholas Denton ${ }^{4}$, Tara C. Steinberg ${ }^{1,2}$ and William Q. \\ $\mathrm{Hua}^{3,5}$
}

\author{
${ }^{I}$ Michael E. DeBakey VA Medical Center Houston, TX, USA \\ ${ }^{2}$ Baylor College of Medicine Houston, TX, USA \\ ${ }^{3}$ San Francisco VA Health Care System, San Francisco, CA, USA \\ ${ }^{4}$ VA Tennessee Valley Healthcare System, Murfreesboro, TN, USA \\ ${ }^{5}$ University of California San Francisco, San Francisco, CA, USA
}

Received: December 19, 2015

Revised: June 15, 2016

Accepted: June 22, 2016

\begin{abstract}
The United States Department of Veterans Affairs (VHA) is the largest provider of Hepatitis C Virus (HCV) care and has made considerable effort in facilitating multidisciplinary medical and mental health care for Veterans with $\mathrm{HCV}$. Those with $\mathrm{HCV}$ are at high risk for psychiatric and substance use disorders that often negatively impact selection for and completion of traditional antiviral treatments. Interferon-based treatments, which were difficult to tolerate due to toxicity and the high occurrence of side effects, were the previous standard for HCV treatment. New interferon-free agents with minimal side effect profiles and improved treatment responses have been developed, which results in more patients being treated for HCV. The VHA's emphasis on multidisciplinary integration and person-centered care highlights the importance of integrating mental health care within $\mathrm{HCV}$ clinical care and provides a rich environment for expanding the role of the clinical health psychologist in hepatology settings. This paper will describe the role of the clinical health psychologist in the past and new era of HCV clinical care, with special consideration placed on the expanding role of the clinical health psychologist given the latest advancements in antiviral treatment for HCV. A review of the clinical health psychologist's role in the following areas will be provided: assessment of treatment candidacy, treatment of mental health and substance use disorders, promotion of adherence, and work with specialty hepatology populations.
\end{abstract}

Keywords: Adherence, Clinical Health Psychologist, Hepatitis C Virus, Integrated Care, Liver Disease, Mental Health, Psychological Evaluation.

\section{INTRODUCTION}

The hepatitis $\mathrm{C}$ virus (HCV) is a blood-borne viral pathogen that is transmitted through exposure to infected blood. In the United States, the majority of current exposure mechanisms include intravenous drug use (IVDU), intranasal cocaine use, and to a lesser extent, being born to an HCV-positive mother, unprotected high risk sexual behaviors (e.g., unprotected high-impact anal sex), blood transfusions prior to 1992, and unsterilized needles used for vaccinations [1]. $\mathrm{HCV}$, a major contributor to chronic liver disease and hepatocellular carcinoma (HCC), affects approximately 3.9 million individuals and is responsible for 8,000-10,000 deaths per year in the United States (U.S.) [2]. While HCV prevalence in the U.S. is $1.8 \%$, the Veterans Health Administration (VHA) has identified that U.S. Veterans carry a risk that is much greater $(5.4 \%$ prevalence) than the general population, with Vietnam-era Veterans at greatest risk

\footnotetext{
* Address correspondence to this author at the Michael E. DeBakey VA Medical Center, 2002 Holcombe Blvd. - MHCL 116, Houston, TX 77030, USA; Tel: 713-791-1414 x23403; Fax: 713-794-7917; E-mail: rose.gonzalez3@va.gov
} 
(11\% prevalence). Thus, there is a strong need for timely and comprehensive care for Veterans living with HCV [2].

Clinical health psychology is a specialty field of applied clinical psychology, and is defined by the American Board of Professional Psychology (ABPP) as "a field that applies scientific knowledge of the interrelationships among behavioral, emotional, cognitive, social, and biological components in health and disease to the promotion and maintenance of health; the prevention, treatment and rehabilitation of illness and disability; and the improvement of the health-care system" [3]. This specialty field is dedicated to the development of knowledge regarding the interface between behavior and health, and to the delivery of high quality services based on that knowledge, to individuals, families, and health care systems [3]. Clinical health psychology specialty training includes advanced doctoral training in the biological, social, and psychological bases of health and disease, and postdoctoral training in various medical setting emphases, such as chronic pain management, infectious diseases, or psycho-oncology [4]. After such training, a boarding process, including written exams and clinical work reviews, must be completed through the ABPP to be credentialed as a clinical health psychologist [3].

Given the advanced skill-set and specialty training in medical settings, clinical health psychologists have an important role in the interdisciplinary treatment and management of individuals over the course of their HCV care and beyond. As clinical health psychologists receive extensive doctoral-level mental health training, postdoctoral specialty training, and sometimes even medical training, these professionals are uniquely positioned to provide general mental health care (e.g., for depression, anxiety) as well as targeted behavioral health care (e.g., for adjustment to illness, adherence) within interdisciplinary medical settings [5]. This paper will provide an overview of HCV clinical care and the integration of specialty mental health with a focus on: past era mental health treatment, the new era of HCV mental health care, the role of the clinical health psychologist in interdisciplinary practice, mental health treatments, and work with special hepatology populations (i.e., patients with HIV/HCV co-infection, neurocognitive changes, and end-stage liver disease).

\section{PAST ERA CLINICAL CARE}

The late 1990's marked the advent of promising HCV treatments when pegylated alfa interferons (interferon) were introduced, an immunomodulatory agent administered subcutaneously. Prognoses were further improved by the development of ribavirin and oral antiviral nucleoside analogues [6]. In 2012, boceprevir and telaprevir, selective HCV nonstructural protein serine protease inhibitors, were the first direct-acting antivirals added to therapeutic options [7]. A successful HCV treatment was achieved when plasma HCV ribonucleic acid (RNA) levels were undetectable 12 to 24 weeks after treatment completion, deemed a sustained virologic response (SVR) [8]. Drug combinations were selected based on patient-specific factors, including gene make-up or genotype, previous treatment resistance, and psychiatric history. Research has identified six genotypes of HCV, with genotypes 1, 2, and 3 comprising 97\% of HCV cases in the U.S [9]. Of genotypes 1, 2, and 3, genotype 1 was the most difficult to achieve a cure. Given the various genotypes, SVR rates for interferon regimens varied greatly, from a low $38 \%$ to $95 \%$ [10].

Side effects of these past era antiviral drug regimens, which were traditionally prescribed from 12-48 weeks, were heterogeneous, but included nausea, headache, anemia, pruritus, and fatigue. Interferon was linked to high rates of psychiatric complications including insomnia, irritability, anxiety, and depression [10, 11]. Additional rare and severe psychiatric side effects included mania, psychosis, and suicidal ideation $[11,12]$. Individuals with a history of clinical depression were at greater risk for exacerbation of depressive symptoms than those without a history [13], with significant depressive symptoms occurring in $21-58 \%$ of these persons who received interferon [12].

\section{Behavioral and Psychological Considerations in HCV Care}

Psychiatric disorders and substance use (termed Mental Health/Substance Use, or MH/SU) concerns are highly prevalent among those diagnosed with HCV, especially in Veteran populations [14, 15]. In a large-scale study of over 22,000 Veterans with HCV receiving services at the Houston VA between 1992 and 1999, the most common mental health conditions were depression (49.5\%), post-traumatic stress disorder (PTSD; 33\%), psychosis (23.7\%), and bipolar disorder (16\%) [14]. Similarly, another study of 300 Veterans with chronic HCV receiving care at the Portland VA found that $81 \%$ were diagnosed with depression, $61.8 \%$ with PTSD, and $19.8 \%$ with bipolar disorder [16].

Substance use is a major risk factor for HCV infection; the primary route of infection is considered to be IVDU [17]. Hagan et al. [18] found that 50-90\% of persons engaging in IVDU test positive for HCV and seroconversion typically began in the first 1-3 years of use. Even among those using non-injected drugs (i.e., cocaine), the occurrence of $\mathrm{HCV}$ is $5-29 \%$, higher than in the general population [19]. Of Veterans with HCV receiving care through the VHA in 
2013, 55\% carried a prior/current diagnosis of alcohol use disorder, 39\% had a prior/current "other and unspecified drug use" diagnosis, and 35\% had a prior/current diagnosis of a stimulant use disorder [20]. Results from Dominitz et al. [2] indicated that within a large sample of Veterans with $\mathrm{HCV}, 78 \%$ reported either IVDU or a blood transfusion.

While alcohol use does not cause HCV, the research suggests that alcohol consumption does alter the course of $\mathrm{HCV}$ and may result in progression of advanced liver disease [21]. Alcohol has also been associated with poor treatment outcomes, treatment discontinuation [22], and development of liver and/or alcoholic cirrhosis [23]. Corrao et al. [24] found that alcohol consumption in addition to HCV increased the risk of cirrhosis nine times more than those with HCV who abstained from alcohol. Other studies have suggested a dose-response relationship between alcohol consumption and risk for cirrhosis, fibrosis, and mortality [25, 26]. Recent findings suggest that heavy alcohol consumption does not impact liver disease progression in and of itself, but has an additive impact on already poor liver functioning among those with chronic HCV and fibrosis [27]. While some studies show strong links, others have failed to show a relationship between excessive alcohol consumption and severity of HCV [21, 28]. Two methodological issues have been hypothesized to account for this discrepancy, such as varied definitions of excessive alcohol use and the possibility of a Type II error (i.e., the failure to reject a false null hypothesis due to statistical error) [27].

\section{HCV Treatment Barriers}

Previous HCV treatment involved a complex, funneling-down process [29] that resulted in more than two thirds of individuals not adequately treated due to the multifactorial barriers that existed in the treatment process, such as barriers with diagnosis, evaluation, and referral [30 - 33]. Evaluation and diagnosis of HCV have been impacted by low rates of uniform and standardized screening. In 2013, the Centers for Disease Control and Prevention (CDC) and VHA recommended focused HCV testing of the birth cohort ranging from 1945 to 1965, as this birth cohort is at higher risk for HCV [34]. By 2011, VHA providers had tested $63.5 \%$ of these individuals within this cohort who were enrolled in care, compared to $40 \%$ of those enrollees born before 1945, and 57\% born after 1965 [29]. Although testing has been a focus at VHA, especially for the 1945-1965 birth cohort, a large percentage of Veterans have not been tested for HCV [29]. Factors that contribute to issues with screening and diagnosis of HCV may include decreased access to resources and care for patients who are homeless or live in rural communities [35].

Once a patient is tested and diagnosed with $\mathrm{HCV}$, follow up care is crucial, though variable due to a number of challenges and barriers. Research examining the referral process has demonstrated that $24-57 \%$ of individuals will miss their first appointment in specialty care clinics for HCV treatment [36]. Once individuals present for treatment, they may discontinue treatment early or not fully adhere to the treatment protocol. In the VHA, these missed opportunities have resulted in Veterans being lost to follow-up and ultimately not receiving the benefits of treatment. Missed opportunities are often attributed to limited access to care. Recent national estimates suggest that HCV-related visits in rural settings occur at very low rates, possibly due to inadequate resources for testing and treatment [37]. Access to care remains a significant barrier and public health burden for those who are not insured and, thus, more likely to use the emergency department than any other type of health care service [37]. In the past era, evaluations for HCV treatment also presented significant treatment barriers as many patients were deemed ineligible candidates for treatment due to $\mathrm{MH} / \mathrm{SU}$ concerns [38]. A disproportionately high percentage (68-84\%) of Veterans had psychiatric disorders or active substance use, and were often delayed for treatment [39, 40] or excluded from interferon-based treatment [41, 42]. Treatments were commonly contingent on abstinence, and individuals with unmanaged psychiatric disorders or active substance use issues were commonly excluded due to the perceived risk of non-adherence or treatment resistance [38, $43,44]$. A review of the literature found that the level of adherence, particularly during the first 12 weeks of treatment, was a strong predictor of SVR for the older regimens; this placed a heavy emphasis on assessing problematic adherence [45]. Among Veterans with HCV, and particularly among those coinfected with HIV, ribavirin-based regimens were found to be more sensitive to non-adherence behaviors than were interferon-based regimens [46].

Numerous studies have examined the negative impact of stigma on persons diagnosed with HCV, which is defined as the reception of discrimination and prejudice motivated by disease status. Approximately $22-100 \%$ of participants of these studies indicated perceived stigma related to $\mathrm{HCV}$ due to the association of the disease with drug use, sexual promiscuity, sexually transmitted diseases such as HIV, and alcohol abuse [47 - 51]. Stigma can lead to fears related to others discovering one's HCV status; thus, stigma can be viewed as a chronic stressor [51]. In a 2006 study by Zacks et al., 55\% of participants reported non-disclosure of HCV status to a physician [51]. Internalized stigma (i.e., adopting self-denigrating beliefs about HCV) accounts for shame, insecurity, and fears of spreading the disease to others by unrealistic means, such as sharing drinking glasses [51]. Stigma has also been correlated with depression, anxiety, and 
anger [51, 52]. In sum, treatment eligibility requirements, access to care, and stigma have historically presented barriers to receiving $\mathrm{HCV}$ care.

\section{Integrated Care}

Despite findings that indicate that psychiatric side effects are a major predictor of early treatment discontinuation [53], research has demonstrated that individuals with a history of $\mathrm{MH} / \mathrm{SU}$ concerns were able to successfully complete HCV interferon-based treatment, especially when provided interdisciplinary medical and mental health care [54 - 58]. One study found that HCV treatment rates were maximized in a methadone-based clinic when a psychologist, specifically, was part of the patient's interdisciplinary care [59]. In two studies conducted by Schaefer et al. [60, 61], clearance rates of HCV among those with prior mental health conditions (50\%) and substance use disorders (53.8\%) were comparable with the SVR rate of a control group (58.8\%). Other studies have demonstrated that strong SVR rates were achieved among individuals with substance use disorder histories, including alcohol use disorders, but only when treatments were provided in the context of interdisciplinary medical and mental health care [59, 62]. Individuals with known histories of clinical depression who were not receiving antidepressant medication at the time of treatment initiation were at higher risk of discontinuation than those with depressive disorders actively taking medications [63]. In a retrospective study that examined the safety and efficacy of HCV treatment with persons with schizophrenia engaged in active mental health care, findings demonstrated SVR and treatment discontinuation rates similar to persons without schizophrenia [33].

Historically, the clinical health psychologist in hepatology clinics often performed evaluations to determine treatment candidacy for $\mathrm{HCV}$ care, thus serving as a type of treatment gatekeeper [38]. The purpose of the comprehensive psychological evaluation was to assist in clinical-decision making based on the identification of individual risks and benefits associated with treatment, assess a patient's readiness and preparedness for treatment, and inform the overall treatment timeline [37, 64, 65]. The Structured Interview for the Treatment of Hepatitis C Virus (SIT-HCV) by Silberbogen et al. [66] was one of the most common psychosocial interviews utilized by clinical health psychologists in determining psychological appropriateness for treatment. Six major areas covered in the psychological assessment included HCV history, understanding of illness and treatment, social support, motivation and adherence history, MH/SU history, and current psychiatric status [66]. In addition to the structured interview, the recommended self-report psychometric battery typically included the Minnesota Multiphasic Personality Inventory- Second Edition (MMPI-2) [67], the Beck Depression Inventory (BDI) [68], the COPE Inventory [69], the Multidimensional Health Locus of Control (MHLC) [70], and a demographics questionnaire [66]. The Millon Behavioral Medicine Diagnostic (MBMD) [71] has also been used in place of the MMPI-2 or as an adjunctive measure. Overall, the clinical health psychologist played a vital role in the past-era HCV clinical care by aiding in the assessment of patient eligibility for interferon-based treatment.

\section{NEW ERA CLINICAL CARE}

The VHA aims to treat all Veterans with HCV who are treatment appropriate and willing to proceed with therapy. According to the Department of Veterans Affairs National Hepatitis C Resource Center Program (VANHCRCP) and the Office of Public Health $(\mathrm{OPH})$, treatment factors to determine HCV treatment candidacy include: stage of liver fibrosis, intolerance or contraindications to interferon and/or ribavirin, adherence to medication and treatment recommendations, treatment duration, SVR, and lack of adequate data regarding real-world safety and effectiveness [34]. In late 2013, the Food and Drug Administration (FDA) approved antiviral treatments sofosbuvir and simeprevir, followed by Harvoni (combination of ledipasvir and sofosbuvir), and most recently, the Viekira Pak (which contains three new drugs: ombitasvir, paritaprevir, and dasabuvir), that are proven to attain high SVR and have low side effect profiles. These interferon-free regimens are less complex (e.g., one pill per day) and involve a shorter treatment duration (e.g., 12-24 weeks versus 24-48 weeks) [38, 64].

In a VHA October 2014 executive summary, the OPH in collaboration with VHA Pharmacy reported on the 'realworld' experience of using sofosbuvir-based treatment regimens for Veterans in the VHA [72]. The report highlighted several important factors that may have accounted for why VHA clinics saw significantly different treatment outcomes for patients on sofosbuvir-based regimens when compared to participants in the clinical trials, which included: an underrepresentation of the Veteran population in clinical trials, limited data for specialty subgroups that Veterans often occupy (i.e., active substance use, cirrhosis), and differences in age (i.e., Veterans treated have an average age of 61 compared to clinical trial average ages between 46-52). Importantly, the summary reported that early discontinuation 
rates among Veterans were higher compared to their clinical trial peers, and for reasons other than virologic failure or death. For example, discontinuation rates among Veterans may have been related to adherence, adverse effects/tolerance, the Veteran's choice to stop therapy, or other psychosocial factors.

The reporting of real-world, on-the-ground experience is important for informing practical treatment strategies, particularly as HCV treatment is being widely expanded because MH/SU comorbidities now do not preclude or defer antiviral therapy. Further, those who had been previously deemed ineligible due to $\mathrm{MH} / \mathrm{SU}$ concerns are now being reconsidered and prescribed the new agents [73]. In addition to the inclusion of persons with MH/SU concerns, the prevalence of HCV will continue to increase throughout the next decade, particularly among the 1945-1965 birth cohort as the prevalence of cirrhosis peaks 40 years from the incidence of infection [74, 75]. As a result, a large number of treatment-naïve Veterans with advanced liver disease are likely to present for treatment [76]. The aging Veteran population of individuals with $\mathrm{HCV}$ is at risk for advanced liver disease progression and gastrointestinal complications, underlining the need for transplant preparation and possible end-of-life care [77]. Given the reality of organ shortages, the hope among providers prescribing interferon-free regimens is the possibility of minimizing and preventing the need for liver transplantation and/or recurrence of HCV post-transplant [78, 79].

In the midst of the transition from past to new era clinical care, many unanswered questions and challenges remain. In the remaining sections of this paper, enduring clinical issues that warrant evaluation will be discussed, as will the shifting role of the clinical health psychologist within the VHA, particularly in regard to interprofessional/integrated practice, mental health treatment for Veterans living with $\mathrm{HCV}$, adherence strategies, and specialty populations that warrant additional attention in the context of the broadening scope of care.

\section{INTERPROFESSIONAL PRACTICE}

Although the literature supports the implementation of interdisciplinary care, few clinics providing HCV care utilize this approach [79]. Within the VHA, interdisciplinary models of care have been increasingly viewed as vital in the implementation of Veteran-centered care [80]. Integrated mental health and medical care has been widely utilized within VHA in an effort to improve and coordinate care, increase communication among providers, and maximize access to care for Veterans experiencing a wide spectrum of MH/SU concerns [80]. The VHA has become a leader in interprofessional health care that promotes health and wellness, thus, reducing the chances of acquiring disease in the future [81]. The VHA utilizes a population-based approach to preventive care through Patient-Aligned Care Teams (PACT), which has been widely implemented within primary care and some specialty clinics. The PACT model is a team-based approach that improves care by ensuring that each Veteran has personalized visits with their primary care provider and streamlined access to other health care providers, including a nurse care manager, social worker, and administrative clerk.

Given the high prevalence of HCV among Veterans, increasing the availability of integrated MH/SU care and medical services remains critical. Integrated care models in the VA have been further extended beyond PACT models of care and include services and programs such as tele-mental health, shared medical appointments (SMA), and Specialty Care Access Network-Extension for Community Health Outcomes (SCAN-ECHO). Each of these services acts as an extension of the PACT model and facilitates access to care for Veterans and consultation for providers at a distance from specialty services. Telehealth-based treatment has a growing evidence base and meets the VHA's goal to provide health care services to Veterans in rural and remote locations [82]. The SMA is a shared office visit in which multiple providers facilitate a group visit. Group visits allow patients to be followed by a variety of providers across disciplines, improves access to care, and promotes efficiency of care [83, 84]. The SCAN-ECHO program is a providerto-provider model that allows specialists to provide expert consultation to generalists via virtual tele-conferencing (Vtel) technology. Thus, Liver SCAN-ECHO extends the reach of HCV specialty care by having liver specialists (which may include hepatologists, pharmacists, nurse practitioners, and psychologists) available for consultation to providers who do not specialize in HCV clinical care. Within these contexts, clinical health psychologists contribute as experts in the identification and treatment of maladaptive health behaviors and are able to provide consultation on $\mathrm{MH} / \mathrm{SU}$ issues as it relates to the treatment of HCV. All three of these services aim to increase integration of medical and mental health care, which is pertinent to HCV care in the new era.

In an effort to support the growing need for clinical health psychologists in the VHA, the VHA Office of Public Health in collaboration with the Office of Academic Affiliations supported the initiation of a specialty clinical psychology postdoctoral fellowship training program in integrated HIV and HCV clinical care in 2011 [85]. The fellowship has since expanded from four positions to eleven fellowship positions nationally, meeting the growing 
demand for integrated mental health care in HIV and liver clinics. Beyond training psychologists in the specialty area of $\mathrm{HIV} / \mathrm{HCV}$ clinical care, this growing training program is focused on raising awareness of this underserved population, decreasing stigma, and most importantly, increasing access to MH/SU services for Veterans with HIV and HCV.

In sum, clinical health psychologists are particularly well equipped to interface with hepatologists, forging a new interdisciplinary field referred to as psychohepatology [45]. Integrated hepatology care models will likely be strongly encouraged in this new treatment era, as numerous treatment studies have indicated that this type of setting results in improved prognoses and treatment outcomes $[33,45]$. The development and delivery of integrated care models supports the VHA's aim for collaborative practice while also reducing barriers to cross-clinic collaboration and health literacy, particularly in the treatment process.

\section{The Psychological Evaluation}

In the new era of $\mathrm{HCV}$ care, the pre-treatment psychological evaluation remains a critical component of the evaluation process; the evaluation can assist in the identification of a Veteran's barriers (e.g. poor adherence to medications) and strengths (e.g. good social support) that might influence or interfere with successful completion of treatment. Assessment of $\mathrm{MH} / \mathrm{SU}$ concerns will remain pertinent for the purposes of providing comprehensive care, but in the context of $\mathrm{HCV}$ treatment specifically, to maximize adherence, as prior studies have indicated that $\mathrm{MH} / \mathrm{SU}$ complicates medication adherence [22]. Briefer screens may be more useful in the context of the newer regimens, and may include the Alcohol Use Disorders Identification Test (AUDIT) [86], Generalized Anxiety Disorder 7-item scale (GAD-7) [87], the Montreal Cognitive Assessment (MoCA) [88], and the Patient Health Questionnaire Depression Scale (PHQ-9) [89]. Brief measures may also act as an initial screening tool, aiding the interdisciplinary liver team in deciding whether a psychological evaluation is warranted, perhaps expediting the process for otherwise healthy treatment candidates. In addition, briefer screens can aid the clinician in monitoring a patient pre-, post-, and throughout treatment.

\section{Treatment Adherence}

Treatment adherence remains a critical, multifactorial issue that may impact treatment success even in the wake of new antiviral therapies that are achieving SVR in shorter periods of time and with fewer side effects when compared to previous treatment protocols [10,90]. According to Bonner and colleagues [30], factors related to non-adherence can be person-specific, treatment-related, or related to the patient-provider relationship. Individual factors related to adherence include: mental health and emotional problems, substance use and abuse, self-efficacy and confidence, health beliefs about illness severity and benefits of treatment, cognitive impairment, socio-economic status, and employment status [30]. Beliefs about illness severity (i.e., willingness to be sick; beliefs about past treatment regimens) and benefits of treatment (e.g., "I'll take it if it works") are commonly referenced in the existing literature as major barriers to adherence but rarely assessed [65]. In a study examining illness uncertainty and depressive symptoms during periods of watchful waiting, $54 \%$ of participants reported moderate levels of illness uncertainty, and $40 \%$ were at risk for clinical depression. Illness uncertainty was significantly correlated with depressive symptoms $(r=0.49, p<0.01)$, while liver progression and stage of fibrosis were not related to either overall [65]. In the context of the new regimens, assessment of illness beliefs and benefits of treatment remain important, particularly for experienced patients who failed to tolerate past treatments. Findings suggest that psychoeducation, a commonly utilized intervention, may not be sufficient in reducing uncertainty or depressive symptoms [65], thus alternate interventions are indicated to assist those with illness apprehension and/or ambivalence.

Treatment factors related to non-adherence include the medication side effect profile, number of pills and dosing regimen, and complexity and duration of treatment [30]. In the new era, these specific adherence factors may be significantly reduced with objectively less complex treatment durations and dosing regimens, and reduced adverse side effects. However, clinical experience tells us new pillbox packaging presents new challenges for Veterans, with dispensing directions that may be interpreted as complex or confusing to the older adult. In addition, as previously mentioned, adherence to ribavirin will continue to constitute monitoring as adverse side effects remain an issue with this often added medication [46]. Lastly, patient-provider relationship factors affecting adherence may include: individual dissatisfaction, a poor working relationship, poor communication, and lack of sufficient and detailed information provided to the patient [30]. A provider may be more reluctant to monitor a non-adherent patient, or may have limited adherence tools available to them to correct the non-adherence, contributing to overall patient dissatisfaction and less than adequate communication. Provider adherence tools may include routine self-report 
adherence screeners, adherence counseling groups, pill boxes, sample pill packaging, and tools to measure or calculate pharmacy refills. The provider's interest in addressing and/or processing adherence challenges while on treatment is also a factor, and may be attenuated by the aforementioned adherence tools that are available in their respective clinic.

Medication adherence is a predictor of successful SVR; thus, it is emphasized in the psychological literature and multiple interventional approaches have been offered to address non-adherence among patients undergoing HCV treatment $[45,91]$. Clinical health psychologists are well suited to intervene by helping patients to identify strategies to improve adherence and address the underlying psychological variables that can impact adherence, such as depression and active alcohol use. In the wake of new antiviral therapies that are achieving SVR in shorter periods of time and with less toxicity and fewer side effects than traditional agents, maximizing medication adherence becomes imperative as a failed trial of these new agents increases resistance $[10,76,90]$. Community-based research shows that psychoeducational efforts, such as a 15 -minute discussion of HCV with a health care provider, significantly increases HCV screening and improves patient follow-through with specialty care referrals [92]. However, systemic constraints on appointment lengths and panel sizes limit physicians' freedom to provide education on medications and the importance of adherence when prescribing HCV treatment. The task of patient education can be shifted to or augmented by clinical health psychologists, which affords medical providers the opportunity to improve efficiency and to endorse interdisciplinary care.

Empirically supported behavioral health treatment protocols are often used by clinical health psychologists to increase adherence and manage comorbid psychiatric symptoms [45]. Specifically, Motivational Interviewing (MI) techniques developed by Rollnick and Miller [93] is a treatment modality often used with medically ill populations in order to facilitate an individual's progress towards health goals by augmenting patient knowledge and maximizing investment in change. MI carries strong empirical support for medication non-adherence and has become the primary treatment approach for this issue [94]. Also, Cognitive-Behavioral Therapy for Adherence and Depression (CBT-AD) [95] is a behavioral health treatment designed to promote adherence to chronic illness treatment protocols while simultaneously providing evidence-based treatment for symptoms of depression. Though not well studied in individuals living with $\mathrm{HCV}$ with comorbid depression, $\mathrm{CBT}-\mathrm{AD}$ has been shown to be effective at improving treatment adherence in individuals living with other chronic conditions, such as HIV [96] and diabetes [97].

\section{MENTAL HEALTH TREATMENT FOR PATIENTS WITH HCV}

Clinical health psychologists, who are utilized by interdisciplinary teams as part of the HCV treatment process, assess baseline mental health functioning, monitor psychiatric symptoms, provide mental health care if psychiatric symptoms emerge, and consult with colleagues regarding behavioral and mental health factors. Individual and group psychotherapies have been determined effective treatment modalities for a variety of psychiatric conditions common in $\mathrm{HCV}$ clinics, such as anxiety and depression [98].

Clinical health psychologists employ a wide range of evidence-based psychotherapy strategies to decrease individual resistance to medication regimens, improve adherence, and motivate individuals to make health behavior changes. Few of these evidence-based treatments have been examined in HCV populations. Existing research supports the use of MI, described above, by psychologists in a multitude of health care settings, including medical and psychiatric clinics $[99,100]$. MI consistently demonstrates robust research findings, and has been used in numerous health populations, including those with tobacco/substance use disorders [101, 102], diabetes [98], HCV [33], hypertension, and obesity [98]. For example, Evon and colleagues [33] conducted a study on individuals wait-listed for $\mathrm{HCV}$ treatment due to $\mathrm{MH} / \mathrm{SU}$ conditions. Those who were given MI-focused treatment in conjunction with case management were $42 \%$ more likely to be approved for interferon for treatment of $\mathrm{HCV}$ at the end of the psychological intervention.

Clinical health psychologists provide a multitude of psychotherapeutic approaches to address the needs of individuals living with HCV across various stages of their illness. For example, subsequent to a new diagnosis, psychoeducation is often utilized to provide information regarding transmission, basic definitions of key terms, treatment options, and prognostic outcome data. Further, clinical health psychologists assist individuals in overcoming internalized stigma and adjusting to their HCV diagnosis. Other interventions that clinical health psychologists utilize are aimed at minimizing distressing somatic symptoms secondary to comorbid medical conditions. These interventional strategies include behavioral strategies for chronic pain [103], Cognitive Behavioral Therapy for Insomnia [104], and self-monitoring approaches for headache/migraine pain [105]. Supportive and crisis services, such as same-day walk-in access and mental health triage are also a valuable addition within liver clinics. Moreover, "curbside" consultation with 
medical providers and psychologists augment interdisciplinary communication and improve the breadth and quality of care [4].

\section{SPECIALITY POPULATIONS: EXPANDING OUR ROLE}

Veterans with HIV-HCV co-infection, neurocognitive difficulties, and end-stage liver disease present unique challenges to integrated care. As previously mentioned, these populations are underrepresented in clinical trials and preliminary reports suggest Veterans treated for $\mathrm{HCV}$ are discontinuing treatment early primarily due to psychosocial factors [72]. Outlined below are considerations for the role of the clinical health psychologist in these special populations within liver care.

\section{HIV/HCV Co-Infection}

High-risk behaviors that may predispose an individual to HCV, such as IVDU and unprotected high-impact anal sex, are the same risk factors for HIV infection and transmission. Co-infection of HCV and HIV occurs in approximately 5-10 million in the Western world. Approximately $15-37 \%$ of Veterans living with HCV have a diagnosis of HIV, whereas the prevalence of HIV is $1.49 \%$ in the non-HCV infected Veteran population [106, 107]. Similar to mono-infection, co-infection is correlated with MH/SU concerns [108].

Undiagnosed or untreated HIV/HCV co-infection has detrimental effects on overall health status and liver disease progression [109, 110]. Research demonstrates that co-infection accelerates the HCV disease process [111], increases risk for cirrhosis of liver [109] and non-response to HCV antiviral medications, increases progression of hepatocellular carcinoma (HCC) [110], accelerates AIDS-defining illnesses, and increases rates of mortality [112, 113]. Among coinfected individuals with access to HIV antiviral treatments, HCV is the leading non-AIDS related cause of death [114]. Use of alcohol among co-infected individuals adds an additional risk, with a 2001 meta-analysis indicating that the relative risk of decompensated liver disease or cirrhosis is 2.9 (95\% confidence interval, 1.7-5.0) in co-infected individuals compared to individuals with HCV mono-infection [108]. The data demonstrates the need to simultaneously screen for HCV and HIV in order to identify, diagnose, and treat those with co-infections in order to maximize treatment outcomes [115]. The clinical health psychologist situated within infectious disease and liver clinics is in a unique position to inform, refer, and monitor co-infected patients, thus increasing collaboration across clinics and strengthening continuity of care.

\section{Neurocognitive Impairment and HCV}

Approximately one third of persons living with HCV demonstrate cognitive impairment [116]. As the HCV population ages and we see an increasing incidence of HCV in those with IVDU [117], a vital role of the clinical health psychologist is to screen for cognitive impairment and provide intervention, when appropriate. Traditionally, neurocognitive changes were only considered in the context of antiviral treatment effects, liver disease, or both. However, current literature has now demonstrated that HCV infection alone, whether through direct neurotoxicity or indirect processes such as inflammation-triggered induction of cytokine cascades, plays a role in the etiology of neurocognitive changes. In other words, cognitive complaints related to HCV infection are independent from neurocognitive changes resulting from advanced liver disease [116, 118], HIV-co-infection [119], and/or substance use [120]. Moreover, HCV serostatus is a risk factor for within-person fluctuations in neurocognitive performance with HCV-positive individuals demonstrating significantly higher levels of variability compared to their seronegative counterparts [116]. According to the existing literature, cognitive domains affected that are correlated with HCV include attention, executive function, information processing speed, working memory, fine motor function, and verbal and visual learning [119].

Collectively, the aforementioned evidence suggests neurocognitive performance is inversely associated with HCV viral load [119], successful SVR can potentially reverse poor neurocognitive performance [118], and HCV-associated cognitive impairments are not necessarily attributable to a history of substance use [120]. Though cognitive status is also influenced by mental health (e.g. depression, PTSD) and physical comorbidities (e.g. fatigue, pain), overall findings indicate cognitive deficits persist after controlling for these comorbidities [118, 119]. Importantly, medical comorbidities pose the greatest risk for poor prognostic outcomes, including elevated risk of death [121].

As liver disease progresses, individuals with HCV are at risk of medical instability due to hepatic encephalopathy (HE) and/or vascular comorbidities. HE is classified into low-grade or minimal hepatic encephalopathy (MHE) versus overt HE. MHE is characterized by subtle neurocognitive impairment whereas overt HE involves changes in mental 
status ranging from disorientation to coma [121]. Even after remission of persistent HE, several neurocognitive impairments persist, including concerns with working memory, processing speed, learning/memory, and executive function [122]. The presence of HE is associated with poor prognosis and more rapid medical instability; therefore, early identification and treatment of MHE is vital. Neuropsychological testing is but one important approach to aid in the detection of HE. In a recent review article [121], the International Society on Hepatic Encephalopathy and Nitrogen Metabolism endorsed both the PSE-Syndrome-Test, and the Repeatable Battery for the Assessment of Neuropsychological Status (RBANS) [123]. While clinical psychologists are not regularly trained in the administration and interpretation of the RBANS, clinical health psychologists are often trained in this screening instrument for dementia and other types of neurocognitive impairment. The RBANS is a valid, standardized measure supported by robust literature for its utility and has demonstrated to be predictive of disability in liver patients [121]. Clinical health psychologists are well-equipped to consult and refer to neuropsychology based on identified concerns in order to further test neuropsychological functioning.

\section{End-Stage Liver Disease And Liver Transplant}

Chronic HCV infection remains the principal indication for liver transplantation [22, 35]. It is well documented that psychological factors influence morbidity, mortality, and quality of life following liver transplantation [124 - 130]. Many organ transplant programs require potential transplant candidates to have a mental health evaluation conducted in order to identify potential barriers to candidacy and provide appropriate care throughout the transplant process - a function that amounts to life sustaining decisions in some cases [131]. Similar to the HCV evaluation process, the involvement of the clinical health psychologist varies widely as do the psychological contraindications for transplant across transplant programs. For instance, behavioral contraindications most often considered include nonadherence and recent alcohol and drug use. However, many psychologists focus their efforts on improving the candidacy of an individual, advocating for deferment rather than rejection with suggestions outlined so the candidate has the opportunity to make recommended changes. Ongoing psychiatric follow-up is warranted post-transplant according to the existent literature [132], with numerous studies being conducted on alcohol consumption following liver transplant [128 - 131]. Approximately $8-22 \%$ of transplanted individuals return to drinking within the first year, $30-40 \%$ by five years [128]. A minimum of six months of abstinence from alcohol, pre-transplant, is the widely accepted objective cutoff; however, there is inconsistent support for duration of abstinence as a predictor of relapse prior to transplant [128, 130]. In a 2008 meta-analysis aimed to clarify the inconsistencies that exist in risk for relapse to alcohol after transplantation, poor social support, family history of alcohol abuse/dependence, and pre-treatment alcohol abstinence of less than six months significantly, though modestly, correlated with alcohol relapse [126].

Tobacco use across all time periods, particularly resumption post-transplant, is an underestimated problem according to existing literature with $39-58 \%$ of liver transplant recipients using tobacco post-transplant [127]. In a 2008 meta-analysis by Dew et al. [126] examining the average rates of use post-transplant, tobacco use was the most prevalent with 10 cases for every 100 persons, per year (PPY) compared to alcohol relapse and illicit drug use (6 and 4, respectively). Taken together, current findings suggest that longer abstinence predicts less risk of alcohol use [129] in combination with other adverse (e.g., depression, tobacco use) and protective factors (e.g., cohabiting partner, insight into alcohol use) [130].

Liver transplantation is the only viable treatment option for individuals with end-stage liver disease. In 2014, about 4,410 liver transplants were performed and 16,216 candidates were on the wait list for a liver in the U.S. at the time of this report (based on OPTN data as of November 23, 2014) [133]. In addition, many individuals get deferred or never make it on the list; thus, most individuals will not receive the life-saving organ they need to survive [134]. Ample opportunity exists for clinical health psychologists to monitor and treat a patient awaiting transplant listing or on listing, as well as those candidates ultimately rejected from listing. Current literature suggests palliative care should be discussed as an option in the initial assessment of the transplant process in order to reduce barriers that might exist when transplant is no longer an option [124]. In sum, the treatment needs for patients with HCV and progressive complications necessitate the involvement of clinical health psychologists, and include the treatment of psychiatric and substance use concerns, neurocognitive and psychological assessment, behavioral health modification, and end-of-life care for patients along the continuum of disease progression.

\section{CONCLUSION}

$\mathrm{HCV}$ remains a highly prevalent disease, and it is particularly concerning for Veterans who carry an increased 
prevalence of HCV and typically have more health comorbidities than non-Veterans [2]. Veterans with HCV experience higher rates of psychiatric disorders, including depression, PTSD, and serious mental illness (e.g., bipolar and psychosis), and substance use (e.g. IVDU) compared to their non-HCV Veteran counterparts [2, 50]. In the late 1990's, interferon-based treatments offered a way to attain remission; however, these agents often exacerbated pre-existing psychiatric conditions and carried unwanted side effects including flu-like symptoms, anxiety, irritability, and insomnia. Many Veterans were deemed ineligible for HCV care due to their MH/SU concerns, which placed them at an increased risk of a poor response to antiviral treatment. In this past "era", clinical health psychologists provided many services within HCV treatment teams including the administration of pre-treatment psychological assessments to determine treatment eligibility, treatment of premorbid $\mathrm{MH} / \mathrm{SU}$ concerns to improve candidacy for HCV treatment, management of the deleterious side effects of the medications, and behavioral health treatment to promote adherence to medication.

New interferon-free agents have been developed marking the advent of a highly effective treatment for HCV that is less complex and shorter in duration [92]. These agents are more tolerable and have improved response rates, and thus are being prescribed more widely to Veterans with HCV [37]. This breakthrough in HCV clinical care allows more patients who were previously deemed ineligible for treatment due to $\mathrm{MH} / \mathrm{SU}$ concerns to be treated. Simultaneously, the expansion of patient-centered health care and holistic approaches to care, particularly in the VHA, are converging to create a new and rich environment for interprofessional collaboration between medical providers and clinical health psychologists [74].

The VHA is leading the charge in integrated care and creation of a health care environment that promotes global wellbeing and health [135]. Interprofessional treatment approaches, such as the Patient Aligned Care Team (PACT) system used in VHA, engage providers in critical evaluation of individualized health needs instead of focusing solely on symptom management. Other services, such as telehealth services, shared medical appointments, and SCAN-ECHO consultation groups, have been implemented to improve access to care for Veterans living with HCV. Moreover, such services offer specialty consultation for mental health providers interested in additional training for specific patientpopulations $[83,84]$.

This evolving treatment landscape has impacted the role of the clinical health psychologist within HCV interdisciplinary teams. While clinical health psychologists will likely continue to perform psychological evaluations to assist with determination of a Veteran's candidacy for HCV medications, their role may expand to include provision of integrated care services for patients with HCV. Empirically supported treatments, such as motivational interviewing, can be implemented by clinical health psychologists to increase treatment motivation and improve adherence to HCV medications. Other integrated services may include psychotherapeutic interventions for psychiatric and behavioral health concerns (e.g. depression, anxiety, adherence to medications), evaluation and treatment of substance use disorders, crisis management, cognitive screening, psychological assessment, and consultation to other providers.

High-risk behaviors and $\mathrm{MH} / \mathrm{SU}$ comorbidities are likely to persist in this population. Treatment should emphasize abstinence and relapse prevention due to the high rates of people who acquired HCV through IVDU [18]. Cross collaboration with specialty substance use programs would be highly beneficial given that a higher level of care is often needed for patients who cannot be well managed at the integrated level of care. Furthermore, programs such as smoking cessation and transplant support groups warrant additional development as these treatments have not been examined empirically within the HCV population.

HCV-related deaths are expected to increase, particularly as individuals with HCV from the 1945-1965 birth cohort continues to age and begin to evidence symptoms of disease complication and progression [136]. Despite the high prevalence of neurocognitive impairment in $\mathrm{HCV}$, screening of cognitive symptoms is infrequently conducted among HCV patients and is not currently used as a standard of practice for clinical health psychologists. Future research should investigate a sensitive clinical measure for early cognitive change to better assess when important neurological/ neuropsychological referrals should be made. Taken together, the work of clinical health psychologists in hepatology settings can become more integrated and expand across the continuum of care for HCV and liver-related disease, including work with patients with HIV-HCV co-infection, neurocognitive conditions, and/or end-stage liver disease.

$\mathrm{HCV}$ treatment would benefit from the elimination of professional silos and enhanced engagement in interdisciplinary collaboration, which would serve to reduce transmission of HCV, promote early detection and outreach to at-risk persons, improve access and adherence to treatment, and decrease individual and systemic barriers to HCV clinical care [137]. Clinical health psychologists draw from their psychological and behavioral health training to assess and treat the intersection of mental health, substance use, and behavioral health needs within medical 
environments. As such, clinical health psychologists can utilize their specialized skill set and draw upon currently existent models of integrated care in the VA to significantly improve and expand quality HCV care for Veterans. Given that the field of hepatology is moving toward an interdisciplinary treatment framework in the new era of non-interferon treatments [74], clinical health psychologists will likely continue to have a significant role in providing the highest quality patient care for patients living with $\mathrm{HCV}$ and other liver diseases.

\section{CONFLICT OF INTEREST}

The authors confirm that this article content has no conflict of interest.

\section{ACKNOWLEDGEMENTS}

Declared none.

\section{REFERENCES}

[1] NIH Consensus Development Program, Office of Disease Prevention Archive website. Available at: https:/consensus.nih.gov/2002/ 2002HepatitisC2002116html.htm. (Accessed June 20, 2016).

[2] Dominitz JA, Boyko EJ, Koepsell TD, et al. Elevated prevalence of hepatitis C infection in users of United States veterans medical centers. Hepatology 2005; 41(1): 88-96. [http://dx.doi.org/10.1002/hep.20502] [PMID: 15619249]

[3] American Board of Professional Psychology website. Available at: http://www.abpp.org/i4a/pages/index.cfm?pageid=3285. (Accessed June 20, 2016)

[4] Belar C, Deardorff W. Clinical health psychology in medical settings, a practitioner's guidebook. 2nd ed. Washington, D.C.: American Psychological Association 2009 [http://dx.doi.org/10.1037/11852-000]

[5] McGuinness KM. The prescribing clinical health psychologist: a hybrid skill set in the new era of integrated healthcare. J Clin Psychol Med Settings 2012; 19(4): 434-40.

[http://dx.doi.org/10.1007/s10880-012-9341-0] [PMID: 23179075]

[6] McHutchison JG, Gordon SC, Schiff ER, et al. Interferon alfa-2b alone or in combination with ribavirin as initial treatment for chronic hepatitis C. N Engl J Med 1998; 339(21): 1485-92. [http://dx.doi.org/10.1056/NEJM199811193392101] [PMID: 9819446]

[7] Sherman KE, Flamm SL, Afdhal NH, et al. Response-guided telaprevir combination treatment for hepatitis C virus infection. N Engl J Med 2011; 365(11): 1014-24. [http://dx.doi.org/10.1056/NEJMoa1014463] [PMID: 21916639]

[8] Swain MG, Lai MY, Shiffman ML, et al. A sustained virologic response is durable in patients with chronic hepatitis C treated with peginterferon alfa-2a and ribavirin. Gastroenterology 2010; 139(5): 1593-601.

[http://dx.doi.org/10.1053/j.gastro.2010.07.009] [PMID: 20637202]

[9] Delwart E, Slikas E, Stramer SL, et al. Genetic diversity of recently acquired and prevalent HIV, hepatitis B virus, and hepatitis C virus infections in US blood donors. J Infect Dis 2012; 205(6): 875-85. [http://dx.doi.org/10.1093/infdis/jir862] [PMID: 22293432]

[10] Kohli A, Shaffer A, Sherman A, Kottilil S. Treatment of hepatitis C: a systematic review. JAMA 2014; 312(6): 631-40. [http://dx.doi.org/10.1001/jama.2014.7085] [PMID: 25117132]

[11] Kelly EM, Corace K, Emery J, Cooper CL. Bipolar patients can safely and successfully receive interferon-based hepatitis C antiviral treatment. Eur J Gastroenterol Hepatol 2012; 24(7): 811-6. [http://dx.doi.org/10.1097/MEG.0b013e3283535c56] [PMID: 22495398]

[12] Raison CL, Demetrashvili M, Capuron L, Miller AH. Neuropsychiatric adverse effects of interferon-alpha: recognition and management. CNS Drugs 2005; 19(2): 105-23.

[http://dx.doi.org/10.2165/00023210-200519020-00002] [PMID: 15697325]

[13] Hotho DM, Bezemer G, Hansen BE, et al. Effects of escitalopram prophylaxis during antiviral treatment for chronic hepatitis C in patients with a history of intravenous drug use and depression. J Clin Psychiatry 2014; 75(10): 1069-77. [http://dx.doi.org/10.4088/JCP.12m07837] [PMID: 25188436]

[14] el-Serag HB, Kunik M, Richardson P, Rabeneck L. Psychiatric disorders among veterans with hepatitis C infection. Gastroenterology 2002; 123(2): 476-82. [http://dx.doi.org/10.1053/gast.2002.34750] [PMID: 12145801]

[15] Loftis JM, Matthews AM, Hauser P. Psychiatric and substance use disorders in individuals with hepatitis C: epidemiology and management. Drugs 2006; 66(2): 155-74.

[http://dx.doi.org/10.2165/00003495-200666020-00003] [PMID: 16451091] 
[16] Fireman M, Indest DW, Blackwell A, Whitehead AJ, Hauser P. Addressing tri-morbidity (hepatitis C, psychiatric disorders, and substance use): the importance of routine mental health screening as a component of a comanagement model of care. Clin Infect Dis 2005; 40(Suppl. 5): S286-91.

[http://dx.doi.org/10.1086/427442] [PMID: 15768336]

[17] Edlin BR. Prevention and treatment of hepatitis C in injection drug users. Hepatology 2002; 36(5)(Suppl. 1): S210-9. [http://dx.doi.org/10.1053/jhep.2002.36809] [PMID: 12407596]

[18] Hagan H, Des Jarlais DC. HIV and HCV infection among injecting drug users. Mt Sinai J Med 2000; 67(5-6): 423-8. [PMID: 11064493]

[19] Tortu S, Neaigus A, McMahon J, Hagen D. Hepatitis C among noninjecting drug users: a report. Subst Use Misuse 2001; 36(4): 523-34. [http://dx.doi.org/10.1081/JA-100102640] [PMID: 11346280]

[20] HCV Viremic Veterans in VHA Care in 2013 who Ever had a VHA Diagnosis of Selected Comorbid Conditions for the Nation website. Available at: http://vaww.hepatitis.va.gov/data-reports/ccr2013/Cond-ComEverInCare-Jan14-HCVVir-2013-All.asp. (Updated January 15, 2015). (Accessed June 20, 2016).

[21] Monto A, Patel K, Bostrom A, et al. Risks of a range of alcohol intake on hepatitis C-related fibrosis. Hepatology 2004; 39(3): 826-34. [http://dx.doi.org/10.1002/hep.20127] [PMID: 14999703]

[22] Anand BS, Currie S, Dieperink E, et al. Alcohol use and treatment of hepatitis C virus: results of a national multicenter study. Gastroenterology 2006; 130(6): 1607-16.

[http://dx.doi.org/10.1053/j.gastro.2006.02.023] [PMID: 16697724]

[23] Pol S, Fontaine H, Carnot F, et al. Predictive factors for development of cirrhosis in parenterally acquired chronic hepatitis C: a comparison between immunocompetent and immunocompromised patients. J Hepatol 1998; 29(1): 12-9. [http://dx.doi.org/10.1016/S0168-8278(98)80173-6] [PMID: 9696487]

[24] Corrao G, Aricò S. Independent and combined action of hepatitis C virus infection and alcohol consumption on the risk of symptomatic liver cirrhosis. Hepatology 1998; 27(4): 914-9. [http://dx.doi.org/10.1002/hep.510270404] [PMID: 9537428]

[25] Bellentani S, Pozzato G, Saccoccio G, et al. Clinical course and risk factors of hepatitis C virus related liver disease in the general population: report from the Dionysos study. Gut 1999; 44(6): 874-80. [http://dx.doi.org/10.1136/gut.44.6.874] [PMID: 10323892]

[26] Harris HE, Ramsay ME, Andrews N, Eldridge KP. Clinical course of hepatitis C virus during the first decade of infection: cohort study. BMJ 2002; 324(7335): 450-3 [http://dx.doi.org/10.1136/bmj.324.7335.450] [PMID: 11859045]

[27] Rüeger S, Bochud PY, Dufour JF, et al. Impact of common risk factors of fibrosis progression in chronic hepatitis C. BMJ [serial on the Internet] 2014. Sep; [cited 2015 February 15]. Available from: http://gut.bmj.com/content/early/2014/09/11/gutjnl-2014-306997.long

[28] Mohsen AH, Easterbrook PJ, Taylor C, et al. Impact of human immunodeficiency virus (HIV) infection on the progression of liver fibrosis in hepatitis C virus infected patients. Gut 2003; 52(7): 1035-40. [http://dx.doi.org/10.1136/gut.52.7.1035] [PMID: 12801963]

[29] Backus LI, Belperio PS, Loomis TP, Yip GH, Mole LA. Hepatitis C virus screening and prevalence among US veterans in Department of Veterans Affairs care. JAMA Intern Med 2013; 173(16): 1549-52. [http://dx.doi.org/10.1001/jamainternmed.2013.8133] [PMID: 23835865]

[30] Bonner JE, Barritt AS IV, Fried MW, Evon DM. Tangible resources for preparing patients for antiviral therapy for chronic hepatitis C. Dig Dis Sci 2012; 57(6): 1439-44. [http://dx.doi.org/10.1007/s10620-012-2142-3] [PMID: 22488633]

[31] North CS, Hong BA, Adewuyi SA, et al. Hepatitis C treatment and SVR: the gap between clinical trials and real-world treatment aspirations. Gen Hosp Psychiatry 2013; 35(2): 122-8. [http://dx.doi.org/10.1016/j.genhosppsych.2012.11.002] [PMID: 23219917]

[32] Volk ML. Antiviral therapy for hepatitis C: why are so few patients being treated? J Antimicrob Chemother 2010; 65(7): 1327-9. [http://dx.doi.org/10.1093/jac/dkq157] [PMID: 20460398]

[33] Evon DM, Simpson K, Kixmiller S, et al. A randomized controlled trial of an integrated care intervention to increase eligibility for chronic hepatitis C treatment. Am J Gastroenterol 2011; 106(10): 1777-86. [http://dx.doi.org/10.1038/ajg.2011.219] [PMID: 21769136]

[34] Chronic hepatitis $\mathrm{C}$ virus (HCV) Infection: Treatment considerations from the department of VVeterans affairs national hepatitis $\mathrm{C}$ resource center program and the office of public health 2014. (Published March 27, 2014. Revised May 13, 2014. Accessed February 5, 2015).

[35] Galbraith JW, Donnelly JP, Franco RA, Overton ET, Rodgers JB, Wang HE. National estimates of healthcare utilization by individuals with hepatitis C virus infection in the United States. Clin Infect Dis 2014; 59(6): 755-64. [http://dx.doi.org/10.1093/cid/ciu427] [PMID: 24917659]

[36] McGowan CE, Fried MW. Barriers to hepatitis C treatment. Liver Int 2012; 32(Suppl. 1): 151-6. [http://dx.doi.org/10.1111/j.1478-3231.2011.02706.x] [PMID: 22212587] 
[37] Panneer N, Lontok E, Branson BM, et al. HIV and hepatitis C virus infection in the United States: whom and how to test. Clin Infect Dis 2014; 59(6): 875-82. [http://dx.doi.org/10.1093/cid/ciu396] [PMID: 24867787]

[38] Rifai MA, Gleason OC, Sabouni D. Psychiatric care of the patient with hepatitis C: a review of the literature. Prim Care Companion J Clin Psychiatry 2010; 12(6): PCC.09r00877.

[39] Rifai MA, Indest D, Loftis J, Hauser P. Psychiatric management of the hepatitis C patient. Curr Treat Options Gastroenterol 2006; 9(6): 508-19. [http://dx.doi.org/10.1007/s11938-006-0007-6] [PMID: 17081484]

[40] Rifai MA, Bozorg B, Rosenstein DL. Interferon for hepatitis C patients with psychiatric disorders. Am J Psychiatry 2004; 161(12): 2331-2. [http://dx.doi.org/10.1176/appi.ajp.161.12.2331] [PMID: 15569919]

[41] Bini EJ, Bräu N, Currie S, et al. Prospective multicenter study of eligibility for antiviral therapy among 4,084 U.S. veterans with chronic hepatitis C virus infection. Am J Gastroenterol 2005; 100(8): 1772-9. [http://dx.doi.org/10.1111/j.1572-0241.2005.41860.x] [PMID: 16086714]

[42] Ho SB, Groessl E, Dollarhide A, Robinson S, Kravetz D, Dieperink E. Management of chronic hepatitis C in veterans: the potential of integrated care models. Am J Gastroenterol 2008; 103(7): 1810-23.

[http://dx.doi.org/10.1111/j.1572-0241.2008.01877.x] [PMID: 18564122]

[43] Falck-Ytter Y, Kale H, Mullen KD, Sarbah SA, Sorescu L, McCullough AJ. Surprisingly small effect of antiviral treatment in patients with hepatitis C. Ann Intern Med 2002; 136(4): 288-92. [http://dx.doi.org/10.7326/0003-4819-136-4-200202190-00008] [PMID: 11848726]

[44] Castéra L, Zigante F, Bastie A, Buffet C, Dhumeaux D, Hardy P. Incidence of interferon alfa-induced depression in patients with chronic hepatitis C. Hepatology 2002; 35(4): 978-9.

[http://dx.doi.org/10.1053/jhep.2002.32104] [PMID: 11915051]

[45] Evon DM, Golin CE, Fried MW, Keefe FJ. Chronic hepatitis C and antiviral treatment regimens: where can psychology contribute? J Consult Clin Psychol 2013; 81(2): 361-74.

[http://dx.doi.org/10.1037/a0029030] [PMID: 22730952]

[46] Lo Re V III, Teal V, Localio AR, Amorosa VK, Kaplan DE, Gross R. Adherence to hepatitis C virus therapy in HIV/hepatitis C-coinfected patients. AIDS Behav 2013; 17(1): 94-103. [http://dx.doi.org/10.1007/s10461-012-0288-9] [PMID: 22907288]

[47] Paterson BL, Backmund M, Hirsch G, Yim C. The depiction of stigmatization in research about hepatitis C. Int J Drug Policy 2007; 18(5): 364-73.

[http://dx.doi.org/10.1016/j.drugpo.2007.02.004] [PMID: 17854724]

[48] Butt G. Stigma in the context of hepatitis C: concept analysis. J Adv Nurs 2008; 62(6): 712-24. [http://dx.doi.org/10.1111/j.1365-2648.2008.04641.x] [PMID: 18503656]

[49] Butt G, Paterson BL, McGuinness LK. Living with the stigma of hepatitis C. West J Nurs Res 2008; 30(2): $204-21$. [http://dx.doi.org/10.1177/0193945907302771] [PMID: 17630381]

[50] Zickmund S, Ho EY, Masuda M, Ippolito L, LaBrecque DR. "They treated me like a leper". Stigmatization and the quality of life of patients with hepatitis C. J Gen Intern Med 2003; 18(10): 835-44.

[http://dx.doi.org/10.1046/j.1525-1497.2003.20826.x] [PMID: 14521647]

[51] Zacks S, Beavers K, Theodore D, et al. Social stigmatization and hepatitis C virus infection. J Clin Gastroenterol 2006; $40(3)$ : $220-4$. [http://dx.doi.org/10.1097/00004836-200603000-00009] [PMID: 16633123]

[52] Golden J, Conroy RM, O’Dwyer AM, Golden D, Hardouin JB. Illness-related stigma, mood and adjustment to illness in persons with hepatitis C. Soc Sci Med 2006; 63(12): 3188-98.

[http://dx.doi.org/10.1016/j.socscimed.2006.08.005] [PMID: 17010490]

[53] Everson GT, Hoefs JC, Seeff LB, et al. Impact of disease severity on outcome of antiviral therapy for chronic hepatitis C: Lessons from the HALT-C trial. Hepatology 2006; 44(6): 1675-84. [http://dx.doi.org/10.1002/hep.21440] [PMID: 17133499]

[54] Rifai MA, Loftis JM, Hauser P. Hepatitis C treatment of veterans with psychiatric illness. Am J Gastroenterol 2006; 101(3): 673-4. [http://dx.doi.org/10.1111/j.1572-0241.2006.473_3.x] [PMID: 16542298]

[55] Rifai MA, Rosestein DL. Hepatitis C and psychiatry. Focus 2005; 3: 194-202.

[56] Rifai MA, Moles JK, Short DD. Hepatitis C treatment eligibility and outcomes among patients with psychiatric illness. Psychiatr Serv 2006; 57(4): 570-2.

[http://dx.doi.org/10.1176/ps.2006.57.4.570] [PMID: 16603757]

[57] Hauser P, Morasco BJ, Linke A, et al. Antiviral completion rates and sustained viral response in hepatitis C patients with and without preexisting major depressive disorder. Psychosomatics 2009; 50(5): 500-5. [http://dx.doi.org/10.1016/S0033-3182(09)70843-6] [PMID: 19855036]

[58] Ghany MG, Strader DB, Thomas DL, Seeff LB. Diagnosis, management, and treatment of hepatitis C: an update. Hepatology 2009; 49(4): 
1335-74.

[http://dx.doi.org/10.1002/hep.22759] [PMID: 19330875]

[59] Dore GJ, Hellard M, Matthews GV, et al. Effective treatment of injecting drug users with recently acquired hepatitis C virus infection. Gastroenterology 2010; 138(1): 123-35.e1-2. [http://dx.doi.org/10.1053/j.gastro.2009.09.019]

[60] Schaefer M, Schmidt F, Folwaczny C, et al. Adherence and mental side effects during hepatitis C treatment with interferon alfa and ribavirin in psychiatric risk groups. Hepatology 2003; 37(2): 443-51. [http://dx.doi.org/10.1053/jhep.2003.50031] [PMID: 12540795]

[61] Schaefer M, Schmidt F, Horn M, Schmid-Wendtner MH, Volkenandt M. Depression during treatment with interferon alpha. Psychosomatics 2004; 45(2): 176 .

[http://dx.doi.org/10.1176/appi.psy.45.2.176] [PMID: 15016930]

[62] Grebely J, Knight E, Genoway KA, et al. Optimizing assessment and treatment for hepatitis C virus infection in illicit drug users: a novel model incorporating multidisciplinary care and peer support. Eur J Gastroenterol Hepatol 2010; 22(3): 270-7. [http://dx.doi.org/10.1097/MEG.0b013e32832a8c4c] [PMID: 20425880]

[63] Mustafa MZ, Schofield J, Mills PR, et al. The efficacy and safety of treating hepatitis C in patients with a diagnosis of schizophrenia. J Viral Hepat 2014; 21(7): e48-51.

[http://dx.doi.org/10.1111/jvh.12234] [PMID: 24533990]

[64] Muir AJ. The rapid evolution of treatment strategies for hepatitis C. Am J Gastroenterol 2014; 109(5): 628-35. [http://dx.doi.org/10.1038/ajg.2014.66] [PMID: 24732866]

[65] Colagreco JP, Bailey DE, Fitzpatrick JJ, Musil CM, Afdhal NH, Lai M. Watchful waiting: role of disease progression on uncertainty and depressive symptoms in patients with chronic hepatitis C. J Viral Hepat 2014; 21(10): 727-33.

[http://dx.doi.org/10.1111/jvh.12207] [PMID: 25280230]

[66] Silberbogen AK, Mori DL, Sogg S. The structured interview for the treatment of hepatitis C virus (SIT-HCV). J Clin Psychol Med Settings 2005; 12(1): 57-69. [http://dx.doi.org/10.1007/s10880-005-0912-1]

[67] Butcher JN, Dahlstrom WG, Graham JR, Kaemmer B. Manual for the restandardization of the Minnesota Multiphasic Personality Inventory: MMPI-2, an interpretive and administrative guide. Minneapolis, MN: University of Minnesota Press 1989.

[68] Beck AT, Ward CH, Mendelson M, Mock J, Erbaugh J. An inventory for measuring depression. Arch Gen Psychiatry 1961; 4(6): 561-71. [http://dx.doi.org/10.1001/archpsyc.1961.01710120031004] [PMID: 13688369]

[69] Carver CS, Scheier MF, Weintraub JK. Assessing coping strategies: a theoretically based approach. J Pers Soc Psychol 1989; 56(2): $267-83$. [http://dx.doi.org/10.1037/0022-3514.56.2.267] [PMID: 2926629]

[70] Wallston KA, Wallston BS, DeVellis R. Development of the multidimensional health locus of control (MHLC) scales. Health Educ Monogr 1978; 6(2): 160-70. [http://dx.doi.org/10.1177/109019817800600107] [PMID: 689890]

[71] Millon T, Antoni M, Millon C, et al. Millon behavioral medicine diagnostic manual. Minneapolis, MN: NCS Pearson 2004.

[72] Treating hepatitis C in Veterans Affairs (VA): Early experience with sofosbuvir-based regimens. VA Office of Public Health/Population Health and VA Pharmacy Benefits Management Services 2014. (Published October 31, 2014. Accessed March 8, 2015).

[73] Bonner JE, Barritt AS IV, Fried MW, Evon DM. Time to rethink antiviral treatment for hepatitis C in patients with coexisting mental health/substance abuse issues. Dig Dis Sci 2012; 57(6): 1469-74. [http://dx.doi.org/10.1007/s10620-012-2141-4] [PMID: 22484494]

[74] Davis GL, Alter MJ, El-serag H, Poynard T, Jennings LW. Aging of hepatitis C virus (HCV)-infected persons in the United States: a multiple cohort model of HCV prevalence and disease progression. Gastroenterology 2010; 138(2): 513-21. 521.e1-6

[75] Deuffic-Burban S, Poynard T, Sulkowski MS, Wong JB. Estimating the future health burden of chronic hepatitis C and human immunodeficiency virus infections in the United States. J Viral Hepat 2007; 14(2): 107-15 [http://dx.doi.org/10.1111/j.1365-2893.2006.00785.x] [PMID: 17244250]

[76] Pawlotsky JM. New hepatitis C therapies: the toolbox, strategies, and challenges. Gastroenterology $2014 ; 146(5): 1176-92$. [http://dx.doi.org/10.1053/j.gastro.2014.03.003] [PMID: 24631495]

[77] Atkins D, Ross D, Kelley M. Acting in the face of uncertainty. Ann Intern Med 2014; 161(4): 300-1 [http://dx.doi.org/10.7326/M14-1344] [PMID: 24934826]

[78] Ruiz I, Feray C, Pawlotsky JM, Hézode C. Patient with decompensated hepatitis C virus-related cirrhosis delisted for liver transplantation after successful sofosbuvir-based treatment. Liver Transpl 2015; 21(3): 408-9. [http://dx.doi.org/10.1002/lt.24051] [PMID: 25420476]

[79] Sylvestre DL, Loftis JM, Hauser P, et al. Co-occurring Hepatitis C, substance use, and psychiatric illness: treatment issues and developing integrated models of care. J Urban Health 2004; 81(4): 719-34. [http://dx.doi.org/10.1093/jurban/jth153] [PMID: 15466851]

[80] Post EP, Metzger M, Dumas P, Lehmann L. Integrating mental health into primary care within the Veterans Health Administration. Fam Syst 
Health 2010; 28(2): 83-90.

[http://dx.doi.org/10.1037/a0020130] [PMID: 20695668]

[81] Reisinger HS, Hunt SC, Burgo-Black AL, Agarwal MA. A population approach to mitigating the long-term health effects of combat deployments. Prev Chronic Dis 2012; 9: E54. [PMID: 22321146]

[82] Tuerk PW, Fortney J, Bosworth HB, et al. Toward the development of national telehealth services: the role of Veterans Health Administration and future directions for research. Telemed J E Health 2010; 16(1): 115-7. [http://dx.doi.org/10.1089/tmj.2009.0144] [PMID: 20043704]

[83] Berger-Fiffy J. The "nuts and bolts" of implementing shared medical appointments: the Harvard Vanguard Medical Associates experience. J Ambul Care Manage 2012; 35(3): 247-56. [http://dx.doi.org/10.1097/JAC.0b013e3182582c0a] [PMID: 22668614]

[84] Kirsh SR, Schaub K, Aron DC. Shared medical appointments: a potential venue for education in interprofessional care. Qual Manag Health Care 2009; 18(3): 217-24. [http://dx.doi.org/10.1097/QMH.0b013e3181aea27d] [PMID: 19609192]

[85] Chartier M, Blais RK, Steinberg T. A psychology postdoctoral fellowship program in integrated HIV and hepatitis C clinical care: rationale, progress, and future directions. Train Educ Prof Psychol 2014. (no pagination specified).

[86] Saunders JB, Aasland OG, Babor TF, de la Fuente JR, Grant M. Development of the alcohol use disorders identification test (AUDIT): WHO collaborative project on early detection of persons with harmful alcohol consumption--II. Addiction 1993; 88(6): $791-804$. [http://dx.doi.org/10.1111/j.1360-0443.1993.tb02093.x] [PMID: 8329970]

[87] Spitzer RL, Kroenke K, Williams JB, Löwe B. A brief measure for assessing generalized anxiety disorder: the GAD-7. Arch Intern Med 2006; 166(10): 1092-7.

[http://dx.doi.org/10.1001/archinte.166.10.1092] [PMID: 16717171]

[88] Nasreddine ZS, Phillips NA, Bédirian V, et al. The montreal cognitive assessment, MoCA: a brief screening tool for mild cognitive impairment. J Am Geriatr Soc 2005; 53(4): 695-9. [http://dx.doi.org/10.1111/j.1532-5415.2005.53221.x] [PMID: 15817019]

[89] Kroenke K, Spitzer RL, Williams JB. The PHQ-9: validity of a brief depression severity measure. J Gen Intern Med 2001; 16(9): 606-13. [http://dx.doi.org/10.1046/j.1525-1497.2001.016009606.x] [PMID: 11556941]

[90] Hagan LM, Wolpe PR, Schinazi RF. Treatment as prevention and cure towards global eradication of hepatitis C virus. Trends Microbiol 2013; 21(12): 625-33. [http://dx.doi.org/10.1016/j.tim.2013.09.008] [PMID: 24238778]

[91] Redulla R, Dudley-Brown S. Adherence and completion in hepatitis C management: a systematic review. Gastroenterol Nurs 2013; 36(1): 53-8.

[http://dx.doi.org/10.1097/SGA.0b013e318281634e] [PMID: 23364367]

[92] Norton BL, Voils CI, Timberlake SH, et al. Community-based HCV screening: knowledge and attitudes in a high risk urban population. BMC Infect Dis 2014; 14: 74. [http://dx.doi.org/10.1186/1471-2334-14-74] [PMID: 24512462]

[93] Miller and Rollnick. Preparing people for change. New York: Guilford Press 2002.

[94] Spoelstra S, Schueller M, Hilton M, Ridenour K. Interventions combining motivational interviewing and cognitive behavior to promote medication adherence: a literature review. J Clin Nurs 2015; 24(9-10): 1163-73. [http://dx.doi.org/10.1111/jocn.12738] [PMID: 25420723]

[95] Safren SA, Gonzalez JS, Soroudi N. Coping with chronic illness: A cognitive-behavioral therapy approach for adherence and depression. Oxford, UK: Oxford University 2008.

[96] Safren SA, O’Cleirigh C, Tan JY, et al. A randomized controlled trial of cognitive behavioral therapy for adherence and depression (CBTAD) in HIV-infected individuals. Health Psychol 2009; 28(1): 1-10. [http://dx.doi.org/10.1037/a0012715] [PMID: 19210012]

[97] Safren SA, Gonzalez JS, Wexler DJ, et al. A randomized controlled trial of cognitive behavioral therapy for adherence and depression (CBTAD) in patients with uncontrolled type 2 diabetes. Diabetes Care 2014; 37(3): 625-33. [http://dx.doi.org/10.2337/dc13-0816] [PMID: 24170758]

[98] Hellerstein DJ, Little SA, Samstag LW, et al. Adding group psychotherapy to medication treatment in dysthymia: a randomized prospective pilot study. J Psychother Pract Res 2001; 10(2): 93-103. [PMID: 11264333]

[99] Chlebowy DO, El-mallakh P, Myers J, Kubiak N, Cloud R, Wall MP. Motivational interviewing to improve diabetes outcomes in African Americans adults with diabetes. West J Nurs Res 2014. [PMID: 24733233]

[100] Bagøien G, Bjørngaard JH, Østensen C, Reitan SK, Romundstad P, Morken G. The effects of motivational interviewing on patients with comorbid substance use admitted to a psychiatric emergency unit - a randomised controlled trial with two year follow-up. BMC Psychiatry 2013; $13: 93$. 
[http://dx.doi.org/10.1186/1471-244X-13-93] [PMID: 23517244]

[101] Lim G, Park I, Park S, Song S, Kim H, Kim S. Effectiveness of smoking cessation using motivational interviewing in patients consulting a pulmonologist. Tuberc Respir Dis (Seoul) 2014; 76(6): 276-83. [http://dx.doi.org/10.4046/trd.2014.76.6.276] [PMID: 25024721]

[102] Satre DD, Delucchi K, Lichtmacher J, Sterling SA, Weisner C. Motivational interviewing to reduce hazardous drinking and drug use among depression patients. J Subst Abuse Treat 2013; 44(3): 323-9. [http://dx.doi.org/10.1016/j.jsat.2012.08.008] [PMID: 22999815]

[103] Keefe FJ, Caldwell DS, Williams DA, et al. Pain coping skills training in the management of osteoarthritic knee pain: A comparative study. Behav Ther 1990; 21: 49-62. [http://dx.doi.org/10.1016/S0005-7894(05)80188-1]

[104] Edinger JD, Olsen MK, Stechuchak KM, et al. Cognitive behavioral therapy for patients with primary insomnia or insomnia associated predominantly with mixed psychiatric disorders: a randomized clinical trial. Sleep 2009; 32(4): 499-510. [PMID: 19413144]

[105] Nicholson RA, Buse DC, Andrasik F, Lipton RB. Nonpharmacologic treatments for migraine and tension-type headache: how to choose and when to use. Curr Treat Options Neurol 2011; 13(1): 28-40. [http://dx.doi.org/10.1007/s11940-010-0102-9] [PMID: 21080124]

[106] Valdiserri RO, Rodriguez F, Holodniy M. Frequency of HIV screening in the Veterans Health Administration: implications for early diagnosis of HIV infection. AIDS Educ Prev 2008; 20(3): 258-64. [http://dx.doi.org/10.1521/aeap.2008.20.3.258] [PMID: 18558822]

[107] Rockstroh JK, Spengler U. HIV and hepatitis C virus co-infection. Lancet Infect Dis 2004; 4(7): 437-44. [http://dx.doi.org/10.1016/S1473-3099(04)01059-X] [PMID: 15219554]

[108] Graham CS, Baden LR, Yu E, et al. Influence of human immunodeficiency virus infection on the course of hepatitis C virus infection: a metaanalysis. Clin Infect Dis 2001; 33(4): 562-9. [http://dx.doi.org/10.1086/321909] [PMID: 11462196]

[109] Backus LI, Boothroyd D, Deyton LR. HIV, hepatitis C and HIV/hepatitis C virus co-infection in vulnerable populations. AIDS 2005; 19(Suppl. 3): S13-9. [http://dx.doi.org/10.1097/01.aids.0000192065.09281.01] [PMID: 16251809]

[110] Andersson K, Chung RT. Hepatitis C Virus in the HIV-infected patient. Clin Liver Dis 2006; 10(2): 303-320, viii. [http://dx.doi.org/10.1016/j.cld.2006.05.002] [PMID: 16971263]

[111] Monga HK, Rodriguez-Barradas MC, Breaux K, et al. Hepatitis C virus infection-related morbidity and mortality among patients with human immunodeficiency virus infection. Clin Infect Dis 2001; 33(2): 240-7. [http://dx.doi.org/10.1086/321819] [PMID: 11418885]

[112] Rothman RE, Ketlogetswe KS, Dolan T, Wyer PC, Kelen GD. Preventive care in the emergency department: should emergency departments conduct routine HIV screening? a systematic review. Acad Emerg Med 2003; 10(3): 278-85. [http://dx.doi.org/10.1111/j.1553-2712.2003.tb02004.x] [PMID: 12615596]

[113] Branson B. Current HIV epidemiology and revised recommendations for HIV testing in health-care settings. J Med Virol 2007; 79(Suppl. 1): S6-S10. [http://dx.doi.org/10.1002/jmv.20972] [PMID: 17874432]

[114] Branson BM, Handsfield HH, Lampe MA, et al. Revised recommendations for HIV testing of adults, adolescents, and pregnant women in health-care settings. MMWR Recomm Rep 2006; 55(RR-14): 1-17. (quiz CE1-4).

[115] Fuller B, Rodriguez V, Linke A, Hauser P. HIV co-testing among veterans with chronic hepatitis c in the veterans health administration. Open Infect Dis J 2011; 5: 91-6. [http://dx.doi.org/10.2174/1874279301105010091]

[116] Morgan EE, Woods SP, Rooney A, Perry W, Grant I, Letendre SL. Intra-individual variability across neurocognitive domains in chronic hepatitis C infection: elevated dispersion is associated with serostatus and unemployment risk. Clin Neuropsychol 2012; 26(4): 654-74. [http://dx.doi.org/10.1080/13854046.2012.680912] [PMID: 22533778]

[117] Cousien A, Tran VC, Deuffic-Burban S, Jauffret-Roustide M, Dhersin JS, Yazdanpanah Y. Dynamic modelling of hepatitis C virus transmission among people who inject drugs: a methodological review. J Viral Hepat 2015; 22(3): 213-29. [http://dx.doi.org/10.1111/jvh.12337] [PMID: 25270261]

[118] Kraus MR, Schäfer A, Teuber G, et al. Improvement of neurocognitive function in responders to an antiviral therapy for chronic hepatitis C. Hepatology 2013; 58(2): 497-504. [http://dx.doi.org/10.1002/hep.26229] [PMID: 23300053]

[119] Sun B, Abadjian L, Rempel H, Monto A, Pulliam L. Differential cognitive impairment in HCV coinfected men with controlled HIV compared to HCV monoinfection. J Acquir Immune Defic Syndr 2013; 62(2): 190-6. [http://dx.doi.org/10.1097/QAI.0b013e31827b61f1] [PMID: 23187938]

[120] Huckans M, Seelye A, Parcel T, et al. The cognitive effects of hepatitis C in the presence and absence of a history of substance use disorder. J Int Neuropsychol Soc 2009; 15(1): 69-82. 
[http://dx.doi.org/10.1017/S1355617708090085] [PMID: 19128530]

[121] Randolph C, Hilsabeck R, Kato A, et al. Neuropsychological assessment of hepatic encephalopathy: ISHEN practice guidelines. Liver Int 2009; 29(5): 629-35.

[http://dx.doi.org/10.1111/j.1478-3231.2009.02009.x] [PMID: 19302444]

[122] Bajaj JS, Schubert CM, Heuman DM, et al. Persistence of cognitive impairment after resolution of overt hepatic encephalopathy. Gastroenterology 2010; 138(7): 2332-40.

[http://dx.doi.org/10.1053/j.gastro.2010.02.015] [PMID: 20178797]

[123] Randolph C, Tierney MC, Mohr E, Chase TN. The repeatable battery for the assessment of neuropsychological status (RBANS): preliminary clinical validity. J Clin Exp Neuropsychol 1998; 20(3): 310-9. [http://dx.doi.org/10.1076/jcen.20.3.310.823] [PMID: 9845158]

[124] Adam SJ. Palliative care for patients with a failed liver transplant. Intens Crit Care Nurs 2000; 16(6): 396-402. [http://dx.doi.org/10.1054/iccn.2000.1530] [PMID: 11091471]

[125] Bravata DM, Olkin I, Barnato AE, Keeffe EB, Owens DK. Health-related quality of life after liver transplantation: a meta-analysis. Liver Transpl Surg 1999; 5(4): 318-31. [http://dx.doi.org/10.1002/1t.500050404] [PMID: 10388505]

[126] Dew MA, DiMartini AF, Steel J, et al. Meta-analysis of risk for relapse to substance use after transplantation of the liver or other solid organs. Liver Transpl 2008; 14(2): 159-72. [http://dx.doi.org/10.1002/lt.21278] [PMID: 18236389]

[127] DiMartini A, Javed L, Russell S, et al. Tobacco use following liver transplantation for alcoholic liver disease: an underestimated problem. Liver Transpl 2005; 11(6): 679-83. [http://dx.doi.org/10.1002/lt.20385] [PMID: 15915490]

[128] DiMartini A, Day N, Dew MA, et al. Alcohol consumption patterns and predictors of use following liver transplantation for alcoholic liver disease. Liver Transpl 2006; 12(5): 813-20. [http://dx.doi.org/10.1002/lt.20688] [PMID: 16528710]

[129] DiMartini A, Dew MA, Fitzgerald MG, Fontes P. Clusters of alcohol use disorders diagnostic criteria and predictors of alcohol use after liver transplantation for alcoholic liver disease. Psychosomatics 2008; 49(4): 332-40. [http://dx.doi.org/10.1176/appi.psy.49.4.332] [PMID: 18621939]

[130] Kelly M, Chick J, Gribble R, et al. Predictors of relapse to harmful alcohol after orthotopic liver transplantation. Alcohol Alcohol 2006; 41(3): 278-83. [http://dx.doi.org/10.1093/alcalc/agh257] [PMID: 16476764]

[131] Collins C, Labott SM. Psychological assessment of candidates for solid organ transplantation. Prof Psychol Res Pr 2007; 2(38): 150-7. [http://dx.doi.org/10.1037/0735-7028.38.2.150]

[132] Daw J. Making a life-or-death difference. Monitor on Psychology [serial online] 2014; 33(3): 60. Available at: http://www.apa.org/monitor/mar02/makinglife.aspx. (Accessed December 19, 2014).

[133] Organ Procurement and Transplantation Network 2014. OPTN Web site. http://www.oprn.org. (Accessed November 23, 2014).

[134] Selvaggi G. Patient selection in liver transplant: when is it the right time to list? Mayo Clin Proc 2008; 83(2): 140-2. [http://dx.doi.org/10.1016/S0025-6196(11)60833-1] [PMID: 18241622]

[135] Backus LI, Belperio PS, Loomis TP, Mole LA. Impact of race/ethnicity and gender on HCV screening and prevalence among U.S. veterans in Department of Veterans Affairs Care. Am J Public Health 2014; 104(Suppl. 4): S555-61. [http://dx.doi.org/10.2105/AJPH.2014.302090] [PMID: 25100421]

[136] Searson G, Engelson ES, Carriero D, Kotler DP. Treatment of chronic hepatitis C virus infection in the United States: some remaining obstacles. Liver Int 2014; 34(5): 668-71.

[http://dx.doi.org/10.1111/liv.12467] [PMID: 24418358]

[137] Romano JL, Hage SM. Prevention and counseling psychology: revitalizing commitments for the 21st century. Couns Psychol 2000; 28 : 733-63.

[http://dx.doi.org/10.1177/0011000000286001]

(C) Gonzalez et al.; Licensee Bentham Open.

This is an open access article licensed under the terms of the Creative Commons Attribution-Non-Commercial 4.0 International Public License (CC BY-NC 4.0) (https://creativecommons.org/licenses/by-nc/4.0/legalcode), which permits unrestricted, non-commercial use, distribution and reproduction in any medium, provided the work is properly cited. 